\title{
The Twentieth-Century Desire for Morphology
}

\section{Marco Tamborini ${ }^{1}$}

Published online: 12 May 2020

(c) The Author(s) 2020

In the history of biology, the study of form inhabits an ambivalent place. Some morphological topics have been explored in depth, whereas the majority of research traditions and practices that featured twentieth-century evolutionary morphology have only marginally been investigated. Until quite recently, scholarship on the history of morphology has focused narrowly on its origin in the nineteenth-century Romantic biology of Johann Wolfgang von Goethe (1749-1832) and others, its reformulation within the Darwinian framework, or its alleged breakdown during the beginning of the twentieth century. Historical interest in the rise and decline of the evolutionary morphology promoted by Ernst Haeckel (1834-1919) and Carl Gegenbauer (1826-1903), for example, has been quite significant. Historians have been occupied at length analyzing the importance of the Haeckel-Gegenbauer school for twentiethcentury morphology, its rise and decline, as well as the role played by Goethe in the growth of either descriptive or idealistic early twentieth century morphology (Richards 2002, 2008; Gliboff 2008; Hopwood 2015; Bowler 1983, 1996; Di Gregorio 2005; Nyhart 1995).

Similarly, we know a great deal about the role of morphology in the so-called Modern Evolutionary Synthesis. Biologist Ernst Mayr sealed morphology's problematic interpretive status in the historiography of the Modern Synthesis when he claimed that "morphology made no concrete contribution to the synthesis, but rather the reverse: the synthesis had an impact on the field of morphology" (Mayr 1980 , p. 173). Several scholars have accepted and strengthened Mayr's reconstruction. Michael Ghiselin, for instance, asserted that "morphology contributed virtually nothing to the synthetic theory of evolution" and hence "failed to contribute to the modern synthesis" (Ghiselin 1980, p. 181, 2006). Another common line of argumentation in the historiography of biology is either the "revolt from" or "breakdown of" morphology (Allen 1975). ${ }^{1}$

\footnotetext{
${ }^{1}$ For exceptions, see, for instance, Hopwood (2003), Love, (2003), and Nyhart (1987, 1995).
}

Marco Tamborini

marco.tamborini@tu-darmstadt.de

1 Institut für Philosophie, Technische Universität Darmstadt, Karolinenplatz 5, 64289 Darmstadt, Germany 
As a result of the diminution of its importance, the majority of research questions, results, and practices characteristic of twentieth-century morphology have been only marginally investigated, if at all, by historians and philosophers of science. Although in recent years a positive trend has become visible, ${ }^{2}$ more efforts are required before we can reach a comprehensive overview. Morphology needs to be investigated more holistically, in terms of how the neo-Darwinian framework, evolutionary developmental biology, as well as digital technologies and engineering approaches to biology all impacted, and were in turn reshaped by, the various morphological traditions over recent decades.

The history of morphology's underdevelopment to date represents a paradoxical exclusion, since, as Manfred Laubichler and Karl Niklas have argued, "in the context of the current biological research we not only see the reappearance of traditional morphological concepts (Bauplan) we also see a return of an organismal perspective, even at the molecular level" (Laubichler and Niklas 2009, p. 297). Several biologists share the same opinion. For instance, evolutionary biologist Massimo Pigliucci has argued that "evolutionary theory has shifted from a theory of form to a theory of genes, and ... it is now in need again of a comprehensive and updated theory of form" (2007, p. 2743). ${ }^{3}$

By presenting a more nuanced picture of the twentieth and twenty-first century science of form, this special issue aims to revise the mainstream historical narrative on evolutionary morphology. It investigates in depth what role the different morphological research traditions of twentieth-century biology play in the development of the biological study of form. Bringing together five case studies, which span the entire twentieth century, this issue explores the morphological practices and outlines the epistemic issues that have shaped current work on the science of form. More precisely, this special issue examines how morphological investigations were integrated into broader biological frameworks and research programs (for example, the Modern Evolutionary Synthesis, evolutionary developmental biology, and synthetic biology), and how morphologists developed their conceptual framework and practices to participate in the rewriting of the agenda of evolutionary theory.

Beyond clarifying the similarities and differences between the socio-cultural and scientific systems in which these five case studies are situated, this special issue presents what I call the "twentieth-century desire for morphology." In 1926, German pathologist Paul Ernst (1859-1937) gave an influential speech at the Assembly of the German Natural Scientists and Physicians (Ernst 1926). In his address, Ernst praised Goethe's approach to life sciences and declared that early twentieth-century biology was permeated by a deep desire for morphology. This desire radiated in various biological disciplines and strongly contrasted with a mechanical and quantitative study of organisms. To satisfy this desire for morphology, Ernst proposed a return to Goethe and an organicist approach to biology. In line with Goethe, organic

\footnotetext{
2 See, for example, Tamborini (2019), Esposito (2016), Love (2003, 2015, 2017), Levit et al. (2014), Hoßfeld and Levit (2012), Rieppel (2016), and Müller (2017).

3 Several biologists defended a similar view. See, for instance, Carroll (2005), Richter and Wirkner (2014), and Müller and Newman (2003).
} 
forms must be considered as pertaining "to both what has been brought forth and the process of bringing-forth" (Goethe [1817] 1999, p. 24, 329; translated in Zammito 2017, p. 483). Furthermore, Ernst noted, morphologists should pursue a "third way" between mechanism and vitalism, given that neither mechanism nor vitalism is the correct approach to grasp and investigate organic form. ${ }^{4}$

Paradigmatically, the five case studies included in this issue show that the same conciliatory desire for morphology endured throughout the entire twentieth century and continues to shape twenty-first century science of form. Although the necessity of proposing a third way between vitalism and mechanism, or a demand to return to Goethe's bio-philosophy, was not entirely shared by all the biologists analyzed here, what they did share was the desire to reaffirm the central role of morphology within evolutionary biology. These biologists expressed a strong desire to re-establish the centrality of the concept of organic form and to analyze its changes over time within mainstream evolutionary research programs. Form investigation, they argued, could help biologists expand on the mechanisms of evolution. In so doing, these morphologists were eager to show that the early- and mid-twentieth century debate over evolutionary mechanisms was not a "noisy affair" (Harwood 1985, p. 279; see also Bowler 1983; Allen 1975). Rather, they claimed that if this topic were tackled from a genuine morphological perspective, further and unexpected evolutionary mechanisms and topics would be uncovered (see Dresow's and Rieppel's papers in this issue).

The desire for morphology became even more intense during the so-called "hardening of the Modern Synthesis of Evolution" (Gould 1983). It became especially tangible in the non-Anglophone and anti-Neo-Darwinian biology of the 1960s and 1970s. It eventually reached its heyday during the 1980s. In fact, with the advent of evolutionary developmental biology, the form problem, as well as the interplay between structurally driven and accidental variation of morphogenetic processes, once again came to the fore. For instance, in order to discuss the role of development in macroevolution during the 1981 meeting that founded evolutionary developmental biology, ${ }^{5}$ biologists investigated how morphological transformations were attained and the role that constraints (see Esposito and Tamborini, this issue) and contingency (see Tamborini, this issue) played in their unfolding.

Hence, first and foremost, this special issue outlines these developments and analyzes the causes and conditions for this symptomatic desire for morphology. In so doing, it offers an intervention within the mainstream historiography of evolutionary theory, expanding and widening the image of evolutionary biology in the twentieth century.

Second, this collection examines how scientists organize their practices and devise new research programs in order to take part in larger scientific debates. One question posed is, in what ways did evolutionary morphologists push to revise their own practices and data in order to converse with the "architects" of the Modern Synthesis and contribute to shifting evolutionary biology's focus "from constraints on

\footnotetext{
4 On the "third way" in early twentieth biology, see, for example, Baedke (2019), Haraway (1976).

5 On this meeting, see Bonner (1982) and Huneman and Walsh (2017).
} 
morphology to the mechanisms that enable or explain morphological evolution-socalled evolvability" (Briggs 2017, p. 204)? Beyond shedding light on the history of a Fachgebiet - evolutionary morphology - this special issue offers an excellent case study to investigate thoroughly how shared fields of research struggle to gain recognition. Accordingly, strategies adopted by morphologists to establish their epistemic and social autonomy throughout the twentieth and twenty-first centuries are highlighted.

Third, these papers focus on a deep and radical transformation within evolutionary morphology. At the end of the nineteenth century, morphology was considered by most biologists as "the first evolutionary science" for analyzing and understanding evolutionary changes thorough time (Bowler 1996, p. 17). During the twentieth century, evolutionary morphologists became increasingly less interested in pursuing historical and phylogenetic explanations. They also lost interest in drawing phylogenetic trees or series of forms. In redefining and expanding their disciplinary space of knowledge, many morphologists started adopting new technologies and developed so-called engineering approaches to the study of evolution. This transition culminated in the establishment of synthetic biology. By investigating how biologists redefine the concept of form to develop an engineering approach to life, this special issue focuses on the intertwinement between evolutionary theory and engineering (see Gramelsberger's and Tamborini's papers). In so doing, it calls attention to the role of modeling, quantitative analysis of biological form, as well as the importance of new, appropriated methodologies (the creation of morphospace and the integration of form with engineering sciences) in twentieth-century morphology.

To conclude, this special issue offers a dynamic picture of the twentieth-century science of form that takes seriously the multilayered connections between knowledge production, its technological setting, and broader philosophical categories. This, I hope, will pave the way for a more comprehensive study of what happened in twentieth-century evolutionary biology. ${ }^{6}$

\section{Acknowledgements Open Access funding provided by Projekt DEAL.}

Open Access This article is licensed under a Creative Commons Attribution 4.0 International License, which permits use, sharing, adaptation, distribution and reproduction in any medium or format, as long as you give appropriate credit to the original author(s) and the source, provide a link to the Creative Commons licence, and indicate if changes were made. The images or other third party material in this article are included in the article's Creative Commons licence, unless indicated otherwise in a credit line to the material. If material is not included in the article's Creative Commons licence and your intended use is not permitted by statutory regulation or exceeds the permitted use, you will need to obtain permission directly from the copyright holder. To view a copy of this licence, visit http://creativecommons.org/licen ses/by/4.0/.

\footnotetext{
${ }^{6}$ For instance, I am currently working on a book-length treatment of this development. See Tamborini, The Architecture of Evolution: The Science of Form in Twentieth-Century Evolutionary Biology (under contract with University of Pittsburgh Press). Further insights into this history can be found in Huneman and Walsh (2017), Peterson (2017), and the book I am currently finishing, "The Architecture of Evolution: The Science of Form in Twentieth-Century Evolutionary Biology."
} 


\section{References}

Allen, Garland E. 1975. Life Science in the Twentieth Century. New York: Wiley.

Baedke, J. 2019. O Organism, Where Art Thou? Old and New Challenges for Organism-Centered Biology. Journal of the History of Biology 52: 293-324. https://doi.org/10.1007/s10739-018-9549-4.

Bonner, John Tyler (Eds.). 1982. Evolution and Development. Report of the Dahlem Workshop on Evolution and Development Berlin 1981, May 10-15. Berlin: Springer.

Bowler, Peer J. 1983. The Eclipse of Darwinism: Anti-Darwinian Evolutionary Theories in the Decades around 1900. Baltimore: Johns Hopkins University Press.

Bowler, Peter J. 1996. Life's Splendid Drama: Evolutionary Biology and the Reconstruction of Life's Ancestry, 1860-1940. Chicago: The University of Chicago Press.

Briggs, Derek Ernest Gilmor. 2017. Seilacher, Konstruktions-Morphologie, Morphodynamics, and the Evolution of form. Journal of Experimental Biology Part B 328 (3): 197-206.

Carroll, Sean B. 2005. Endless Forms Most Beautiful: The New Science of Evo Devo and the Making of the Animal Kingdom. London: Quercus.

Di Gregorio, Mario. 2005. From Here to Eternity: Ernst Haeckel and Scientific Faith. Göttingen: Vandenhoeck \& Ruprecht.

Ernst, Paul. 1926. Das morphologische Bedürfnis. Die Naturwissenschaften 14: 1075-1080.

Esposito, Maurizio. 2016. Romantic Biology, 1890-1945. London: Routledge.

Ghiselin, Michael. 1980. The Failure of Morphology to Assimilate Darwinism. In The Evolutionary Synthesis: Perspectives on the Unification of Biology, ed. E. Mayr and W. Provine. Cambridge, MA: Harvard University Press.

Ghiselin, Michael. 2006. The Failure of Morphology to Contribute to the Modern Synthesis. Theory in Biosciences 124: 309-316.

Gliboff, Sander. 2008. H.G. Bronn, Ernst Haeckel, and the Origins of German Darwinism A Study in Translation and Transformation. Cambridge, MA: MIT Press.

Goethe, Johann Wolfgang von. (1817) 1999. Bildung und Unbildung. Frankfurt: Deutscher Klassiker Verlag.

Gould, Stephen Jay. 1983. The Hardening of the Modern Synthesis. In Dimensions of Darwinism, ed. M. Green. Cambridge: Cambridge University Press.

Haraway, Donna Jeanne. 1976. Crystals, Fabrics and Fields: Metaphors That Shape Embryos. New Haven, CT: Yale University Press.

Harwood, Jonathan. 1985. Geneticists and the Evolutionary Synthesis in Interwar Germany. Annals of Science 42 (3): 279-301.

Hopwood, Nick. 2003. Embryology. In The Cambridge History of Science: The Modern Biological and Earth Sciences, vol. 6, ed. P. Bowler and J. Pickstone. Cambridge: Cambridge University Press.

Hopwood, Nick. 2015. Haeckel's Embryos: Images, Evolution, and Fraud. Chicago: University of Chicago Press.

Hoßfeld, Uwe, and Georgy S. Levit. 2012. Hans Böker-Biomorphologe, Amazonasforscher und Holist. Biologie in unserer Zeit 42 (3): 197-198.

Huneman, Philippe, and Denis M. Walsh. 2017. Challenging the Modern Synthesis: Adaptation, Development, and Inheritance. Oxford: Oxford University Press.

Laubichler, Manfred D., and Karl J. Niklas. 2009. The Morphological Tradition in German Paleontology: Otto Jaekel, Walter Zimmermann, and Otto Schindewolf. In The Paleobiological Revolution: Essays on the Growth of Modern Paleontology, ed. D. Sepkoski and M. Ruse. Chicago: University of Chicago Press.

Levit, Georgy S., Uwe Hossfeld, and Lennart Olsson. 2014. The Darwinian Revolution in Germany: From Evolutionary morphology to the Modern Synthesis. Endeavour 38: 268-279.

Love, Alan. 2003. Evolutionary Morphology, Innovation, and the Synthesis of Evolutionary and Developmental Biology. Biology and Philosophy 18 (2): 309-345.

Love, Alan. 2015. Conceptual Change and Evolutionary Developmental Biology. In Conceptual Change in Biology. Scientific and Philosophical Perspectives on Evolution and Development, ed. Alan Love. Heidelberg: Springer.

Love, Alan. 2017. Evo-devo and the Structure(s) of Evolutionary Theory: A Different Kind of Challenge. In Challenging the Modern Synthesis: Adaptation, Development, and Inheritance, ed. P.W. Huneman and M. Denis. Oxford: Oxford University Press. 
Mayr, Ernst. 1980. Morphology. In The Evolutionary Synthesis: Perspectives on the Unification of Biology, ed. E. Mayr and W. Provine. Cambridge, MA: Harvard University Press.

Müller, Gerd B. (ed.). 2017. Vivarium. Experimental, Quantitative, and Theoretical Biology at Vienna's Biologische Versuchsanstalt. Cambridge, MA: MIT Press.

Müller, Gerd B., and Stuart A. Newman (eds.). 2003. Origination of Organismal Form: Beyond the Gene in Developmental and Evolutionary Biology. Cambridge, MA: MIT Press.

Nyhart, Lynn K. 1987. The Disciplinary Breakdown of German Morphology, 1870-1900. Isis 78 (3): 365-389.

Nyhart, Lynn K. 1995. Biology Takes Form. Animal Morphology and the German Universities 18001900. Chicago: University of Chicago Press.

Peterson, Erik L. 2017. The Life Organic: the Theoretical Biology Club and the Roots of Epigenetics. Pittsburgh: University of Pittsburgh Press.

Pigliucci, Massimo. 2007. Do We Need an Extended Evolutionary Synthesis? Evolution: International Journal of Organic Evolution 61 (12): 2743-2749.

Richards, Robert J. 2002. The Romantic Conception of Life: Science and Philosophy in the Age of Goethe. Chicago: University of Chicago Press.

Richards, Robert J. 2008. The Tragic Sense of Life. Ernst Haeckel and the Struggle over Evolutionary Thought. Chicago: University of Chicago Press.

Richter, Stefan, and Christian S. Wirkner. 2014. A Research Program for Evolutionary Morphology. Journal of Zoological Systematics and Evolutionary Research 52 (4): 338-350.

Rieppel, Olivier. 2016. Phylogenetic Systematics: Haeckel to Hennig. London: CRC Press.

Tamborini, Marco. 2019. Series of Forms, Visual Techniques, and Quantitative Devices: Ordering the World Between the End of the 19th and Early 20th Centuries. History and Philosophy of the Life Sciences 41: 49. https://doi.org/10.1007/s40656-019-0282-x.

Zammito, John H. 2017. The Gestation of German Biology: Philosophy and Physiology from Stahl to Schelling. Chicago, IL: University of Chicago Press.

Publisher's Note Springer Nature remains neutral with regard to jurisdictional claims in published maps and institutional affiliations. 